\title{
COMPARISON BETWEEN AGE AND LEFT VENTRICULAR EJECTION FRACTION IN PREDICTION OF RENAL DYSFUNCTION IN CARDIORENAL SYNDROME TYPE 1 AND 2
}

\author{
Dijana Stojanović ${ }^{1}$, Sonja Radenković1,2, Jelena Radović1, \\ Miodrag Stojanović ${ }^{3,5}$, Danijela Tasićs ${ }^{3}$ Sandra Šarić4, \\ Valentina Mitić
}

\begin{abstract}
Cardiorenal syndrome type 1 represents an acute decompensation of cardiac function leading to acute renal failure, and cardiorenal syndrome type 2 represents chronic abnormalities in myocardial function leading to aggravated chronic kidney disease. The aim of this study was to assess renal function changes in patients hospitalized with heart failure, de novo and acute decompensated, and to evaluate some of the risk factors for renal dysfunction.

A total of 580 patients with heart failure were included in the study. The subgroup of patients with renal dysfunction (368 patients, mean age $70.29 \pm 9.75$ ) was observed according to: age, sex, and type of heart failure (systolic and diastolic dysfunction). We used logistic regression to calculate non-adjusted ORs and $95 \%$ confidence intervals for glomerular filtration rate $<60 \mathrm{ml} / \mathrm{min} / 1.73 \mathrm{~m}^{2}$ and to determine best risk factors for development of kidney dysfunction.

Renal dysfunction was confirmed in $63.44 \%$ of patients with heart failure. Nonadjusted OR showed that there was a significant risk for the development of renal damage with age $(O R=5.610 ; p<0.001)$, and with the presence of systolic dysfunction $(\mathrm{OR}=$ $1.978 ; p<0.001)$. The presence of diastolic dysfunction and gender did not have any impact on the development of renal damage.

We demonstrated that patient's age and systolic dysfunction were significant risk factors for the development of renal damage in patients with heart failure, while diastolic dysfunction and gender did not have any significance. Comparing ORs, age was a better predictor of renal dysfunction in cardiorenal syndromes type 1 and 2 than systolic dysfunction.
\end{abstract}

Acta Medica Medianae 2017;56(4):120-125.

Key words: Age, cardiorenal syndromes type 1 and 2, heart failure, left ventricular ejection fraction, renal dysfunction

\author{
${ }^{1}$ University of Niš, Medical Faculty Niš, Institute of \\ Pathophysiology, Serbia \\ ${ }^{2}$ Clinic for Nephrology, Dialysis and Transplantation, Clinical \\ Centre Niš, Serbia \\ ${ }^{3}$ Institute for Public Health, Niš, Serbia \\ 4Institute for Treatment and Rehabilitation "Niška Banja", Niška \\ Banja, Serbia \\ ${ }^{5}$ University of Niš, Medical Faculty Niš, Niš, Serbia \\ Contact: Dijana Stojanovic \\ Bul. dr Zorana Đinđića 81, 18000 Niš, Serbia \\ E-mail: dijanam24@hotmail.com
}

\section{Introduction}

The term 'Cardiorenal Syndromes' (CRS) refers to heart and kidney disorders, where acute 120 or chronic dysfunction in one organ may induce acute or chronic dysfunction of the other (1), and these are divided into five different subcategories (2), each of them with different pathophysiologic mechanisms.

Cardiorenal syndrome type 1 represent acute decompensation of cardiac function leading to acute renal failure, where worsening of renal function complicates acute decompensated heart failure (ADHF) and acute coronary syndrome (3). On the other hand, cardiorenal syndrome type 2 describes chronic abnormalities in myocardial function leading to aggravated chronic kidney disease (3). According to heart failure (HF) registry databases, renal dysfunction (RD) is the most frequent comorbidity in $\mathrm{HF}$ patients associated with high in-patient mortality rates (4). Patients with acute HF can be classified as de novo HF and acu- 
te decompensated HF depending on the onset and duration of their symptoms (5).

In patients with acute HF, hemodynamic balance, maintained by the kidneys is often disrupted, resulting in decreased organ perfusion and ultimately organ failure and possibly death. Acute HF is characterized by diminished left ventricular systolic function and poor cardiac output, activating compensatory mechanisms such as the reninangiotensin-aldosterone system, sympathetic system, and other local mediators, which interact to maintain the fluid volume (6-8). Furthermore, decreased renal perfusion, in addition to nephrotoxic agents and over-diuresis, eventually leads to acute kidney injury (AKI) in such patients (5). The end result of these hemodynamic disturbances in the kidney is a loss of auto regulation and the onset of worsened salt and water retention, reduction in renal filtration, and oliguria (2).

Due to that knowledge, the aim of this study was to assess the changes in renal function in patients hospitalized with acute heart failure, de novo and acute decompensated, and to determine the risk factors for the development of renal dysfunction.

\section{Patients and methods}

We observed 580 patients with HF (de novo and acutely decompensated), of both genders, hospitalized in the Clinic for Cardiovascular Diseases, Clinical Centre Niš, Serbia, between March and November 2014. The investigation was designed as a cross-sectional study. It was approved by the Ethic Committee of the Clinical Center Niš and conducted in compliance with the Declaration of Helsinki and Good Clinical Practice Guidelines.

The diagnosis of HF was based on the diagnostic principles of the European Society of Cardiology (ESC) (9), and all patients with left ventricular ejection fraction (LVEF) $\leq 45 \%$, or with diastolic heart failure having the New York Heart Association function (NYHA) class II to IV (10) were enrolled in the study. Echocardiography was performed on the VIVID 4GE ultrasound system and LVEF was measured according to the Simpson method (11). Patients with de novo HF did not have any previous symptoms and signs of $\mathrm{HF}$, and patients with acute decompensated HF had preexisting heart disease. The majority of the patients had coronary artery disease, hypertension and mitral regurgitation, as the main underlying conditions for the development of HF.

A fasting blood sample $(5 \mathrm{~mL})$ was obtained from each participant and all biochemical measurements were obtained using standard clinical laboratory methods, and all analysis were performed on the Erba Mannheim XL600 analyzer (ERBA Diagnostics Mannheim Gmbh, Baden-Wurttemberg, Germany).

Elevated creatinine was defined as the values exceeding $115 \mu \mathrm{mol} / \mathrm{L}$, and urea was taken to be elevated if higher than $6,5 \mathrm{mmol} / \mathrm{L}$, with regard to the reference values in our laboratory. For the estimation of glomerular filtration rate (eGFR) we used the Modification of Diet in Renal Disease (MDRD) formula. Kidney dysfunction was defined as eGFR $<60 \mathrm{ml} / \mathrm{min} / 1.73 \mathrm{~m}^{2}$.

The clinical group of patients with HF was further divided into two subgroups according to the presence of renal dysfunction (RD). The first subgroup of patients with renal damage consisted of $368(63.44 \%)$ patients. In the second subgroup there were $212(36.55 \%)$ patients with normal renal function used as controls. The subgroup of patients with renal dysfunction was further analyzed according to the following factors: age - 279 (75.8\%) patients were older than 65 years and 89 $(24.2 \%)$ were younger; sex - there were 188 (51.08\%) males and 180 (48.92\%) females; type of heart failure - systolic dysfunction was observed in 175 (47.55\%) patients and diastolic in 193 (52.44\%). They all received diuretics during their hospital treatment.

\section{Statistical Analyses}

The characteristics of the study group were expressed as mean \pm SD (continuous variables) with the number and \% in brackets (categorical variables). We compared the patient data using Student t-test for normally distributed data (expressed as mean \pm SD). Univariate logistic regression was used to calculate the Odds Ratio (OR) and 95\% Confidence Intervals (CI) for eGFR $<60 \mathrm{ml} / \mathrm{min} / 1.73 \mathrm{~m}^{2}$. The structure of patients according to the type of renal dysfunction was presented as a box plot figure. The relationship between selected variables was determined by the Pearson's correlation coefficient ( $r$ ). All the analyses were performed with SPSS version 10.0 (SPSS, Chicago, IL, United States) at the significance level set at $p<0.05$.

\section{Results}

Renal dysfunction was confirmed in 368 $(63.44 \%)$ patients with heart failure. Out of them, $234(63.6 \%)$ were the patients with elements of chronic kidney disease, 59 (16\%) had acute kidney function reduction, while in 75 (20.4\%) there was a deterioration of already present chronic failure. Significant differences were found between patients in the following: age $(p<0.05)$, LVEF $(p<$ $0.001)$, urea $(p<0.001)$, creatinine ( $p<0.001)$, and eGFR ( $p<0.001$ ) (all data presented in Table 1$)$.

Comparing the parameters of global renal function (plasma concentration of urea, creatinine and eGFR) and LVEF (\%) in the subgroup of patients with HF who developed renal dysfunction, we found the following: urea concentration was significantly higher in patients older than 65 years than in younger ones ( $p<0.001)$, and in females compared to males $(p<0.05)$. Creatinine concentration was significantly higher in patients older than 65 years compared to younger ones ( $p<$ $0.05)$. The values of eGFR were significantly lower 
in patients older than 65 years $(p<0.001)$, in males compared to females ( $p<0.001)$, and in patients with systolic dysfunction $(p<0.01)$. The values of $\operatorname{LVEF}(\%)$ were significantly lower in patients older than 65 compared to younger ones $(p<0.05)$, in females compared to males ( $p<$ $0.01)$, and in those with systolic $(p<0.001)$ and diastolic dysfunction $(p<0.01)$ (all data presented in Table 2).

Table 1. Baseline characteristics of patients hospitalized with heart failure

\begin{tabular}{||c||c|c|c||}
\hline Parameter & $\begin{array}{c}\text { Patients with normal kidney } \\
\text { function }(\mathrm{N}=212)\end{array}$ & $\begin{array}{c}\text { Patients with renal dysfunction } \\
(\mathrm{N}=368)\end{array}$ & $\mathrm{p}$ \\
\hline \hline Age & $59.83 \pm 12.22$ & $70.29 \pm 9.75^{*}$ & 0.05 \\
\hline LVEF $(\%)$ & $50.61 \pm 12.33$ & $37.52 \pm 13.21^{* *}$ & 0.001 \\
\hline Urea $(\mathrm{mmol} / \mathrm{L})$ & $5.26 \pm 1.17$ & $11.19 \pm 6.88^{* * *}$ & 0.001 \\
\hline Creatinine $(\mu \mathrm{mol} / \mathrm{L})$ & $85.50 \pm 13.31$ & $137.16 \pm 105.31^{* * *}$ & 0.001 \\
\hline eGFR $\left(\mathrm{ml} / \mathrm{min} / 1,73 \mathrm{~m}^{2}\right)$ & $78.75 \pm 13.30$ & $51.43 \pm 17.20^{* * *}$ & 0.001 \\
\hline
\end{tabular}

Data are expressed as $\bar{X} \pm \mathrm{SD}$-compared with Student- $t$ test

LVEF-left ventricular ejection fraction; eGFR- estimated glomerular filtration rate.

Table 2. The comparison of risk factors for renal dysfunction in patients with heart failure

\begin{tabular}{||c|c|c|c|c|c|c||}
\hline \hline \multicolumn{2}{||c|}{ Parameters } & $\mathrm{N}$ & $\begin{array}{c}\text { Urea } \\
(\mathrm{mmol} / \mathrm{L})\end{array}$ & Creatinine $(\mu \mathrm{mol} / \mathrm{L})$ & $\begin{array}{c}\text { eGFR } \\
\left(\mathrm{ml} / \mathrm{min} / 1,73 \mathrm{~m}^{2}\right)\end{array}$ & $\begin{array}{c}\text { LVEF } \\
(\%)\end{array}$ \\
\hline \hline \multirow{2}{*}{ Age } & $<65$ & 89 & $7.14 \pm 4.25$ & $117.87 \pm 39.23$ & $62.29 \pm 19.59$ & $45.99 \pm 13.4$ \\
\cline { 2 - 8 } & $>65$ & 279 & $10.22 \pm 6.94^{* * *}$ & $124.96 \pm 48.25^{*}$ & $54.49 \pm 18.17^{* * *}$ & $43.29 \pm 12.6^{*}$ \\
\hline \multirow{2}{*}{ Sex } & $\mathrm{m}$ & 188 & $8.57 \pm 4.93$ & $118.73 \pm 50.26$ & $67.04 \pm 19.67$ & $43.08 \pm 12.8$ \\
\cline { 2 - 8 } & $\mathrm{f}$ & 180 & $9.63 \pm 7.56^{*}$ & $117.84 \pm 69.98$ & $53.90 \pm 19.48^{* * *}$ & $46.07 \pm 13.1^{* *}$ \\
\hline \hline \multirow{2}{*}{ SD } & no & 173 & $8.09 \pm 6.19$ & $115.95 \pm 78.41$ & $66.68 \pm 19.57$ & $59.46 \pm 7.81$ \\
\cline { 2 - 8 } & yes & 175 & $9.13 \pm 5.77$ & $121.45 \pm 78.77$ & $60.07 \pm 20.53^{* *}$ & $39.46 \pm 10.3^{* * *}$ \\
\hline \hline \multirow{2}{*}{ DD } & no & 291 & $9.18 \pm 6.19$ & $116.85 \pm 68.77$ & $60.77 \pm 21.27$ & $42.71 \pm 9.3$ \\
\cline { 2 - 8 } & yes & 193 & $8.62 \pm 5.60$ & $115.11 \pm 68.72$ & $62.43 \pm 19.75$ & $45.73 \pm 15.3^{* *}$ \\
\hline \hline
\end{tabular}

Data are expressed as $\bar{X} \pm \mathrm{SD}$-compared with Student-t test

eGFR-estimated glomerular filtration rate; SD-systolic dysfunction; DD-diastolic dysfunction; LVEF-left ventricular ejection fraction.

Table 3. Non-adjusted Odds Ratio (OR) and $95 \%$ confidence intervals (CI) for renal dysfunction in studied patients

\begin{tabular}{|c|c|c|c|c|c|c|}
\hline & & Without renal dysfunction & With renal dysfunction & OR & $95 \% \mathrm{CI}$ & $p$ \\
\hline Age & {$[<65]$} & $136(60.4)$ & $89(39.6)$ & \multirow{2}{*}{5.610} & \multirow{2}{*}{$3.881-8.108$} & \multirow{2}{*}{$<0.001$} \\
\hline & $65+$ & $76(21.4)$ & $279(78.6)$ & & & \\
\hline Sex & $\mathrm{m}$ & $112(52.83)$ & $188(51.08)$ & \multirow{2}{*}{1.027} & \multirow{2}{*}{$0.994-1.061$} & \multirow{2}{*}{0.110} \\
\hline & $\mathrm{f}$ & $100(47.17)$ & $180(48.92)$ & & & \\
\hline SD & [no] & $69(49.3)$ & $77(32.9)$ & \multirow{2}{*}{1.978} & \multirow{2}{*}{$1.343-2.912$} & \multirow{2}{*}{0.001} \\
\hline & yes & $143(32.9)$ & $175(47.55)$ & & & \\
\hline DD & [no] & $101(37.7)$ & $167(62.3)$ & \multirow{2}{*}{1.068} & \multirow{2}{*}{$0.761-1500$} & \multirow{2}{*}{0.704} \\
\hline & yes & $111(36.2)$ & $193(52.44)$ & & & \\
\hline
\end{tabular}

Data are expressed as $\mathrm{N}(\%)$.

[ ]-reference categories.

SD - systolic dysfunction; DD - diastolic dysfunction.

Non-adjusted Odds Ratio (OR) for renal dysfunction was presented in Table 3 . Non-adjusted OR showed that there was a significant risk for the development of renal damage with age $(\mathrm{OR}=$ $5.610 ; 95 \%$ CI $3.881-8.108, \mathrm{p}<0.001)$, and with the presence of systolic dysfunction $(\mathrm{OR}=1.978$;
$95 \%$ CI 1.343-2.912, $\mathrm{p}<0.001)$. The presence of diastolic dysfunction and gender did not have any impact on the development of renal damage.

There was a significant positive correlation between LVEF and eGFR values $(r=0.121 ; p=$ 0.004 ), while no significant correlation was found 
between LVEF and urea and creatinine values in our patients with renal dysfunction. We found a negative correlation between age and eGFR values in renal dysfunction patients $(r=-0.425 ; \mathrm{p}<$ $0.001)$.

\section{Discussion}

Heart failure is the leading cause of hospitalization in the age group of 65 years and older, represents a significant economic burden (6), and eventually leads to kidney injury. Renal dysfunction is a common finding in HF patients, and its frequency ranges from 35 to $70 \%$ in various studies $(12,13)$, and has a high in-patient mortality (14). In a meta-analysis, unadjusted mortality rate at one year follow-up was $51 \%$ in those with moderate to severe renal impairment, compared to $26 \%$ in those without any renal impairment (15). The prevalence of RD in our hospitalized patients with HF was $63.3 \%$, which was almost 3 times higher compared to other studies (16), where "moderate" renal failure was found (creatinine clearance $<60 / \mathrm{ml} / \mathrm{min} / \mathrm{m}^{2}$ ) in $22.5 \%$ of patients. On the other hand, in the Valsartan in Heart Failure(Val-HeFT)trial $(17)(n=5010)$, eGFR was found to be below $60 \mathrm{ml} / \mathrm{min} / \mathrm{m}^{2}$ at baseline in $58 \%$ of patients. In both studies, decreased eGFR was a factor of bad prognosis.

Almost half of our HF patients (40\%) showed the elements of chronic kidney damage. Chronic kidney disease (CKD) is reported to increase the number of hospitalizations due to worsening of $\mathrm{HF}$, and these individuals have a high likelihood of cardiovascular death (13). In comparison to chronic, acute renal injuries are reported less frequently in these patients, which was also the case in our study. The possible mechanisms for ARI are arterial hypotension followed by severe kidney hypoperfusion. A part of our patients, precisely $10.2 \%$ of them with HF, developed rapid decrease in kidney function at hospital admission. The incidence of renal function deterioration with already present chronic failure was somewhat higher $(12.9 \%)$ in our patients. Age and baseline renal function were determined as risk factors for ARI and exacerbations in chronic HF patients receiving diuretics (18).

Several studies showed that the prevalence of kidney failure rises with age (16-19). In accordance with that, significantly more patients older than 65 years had RD in this study, and this was an independent risk factor for its occurrence. The traditional risk factors for heart disease, such as hypertension, diabetes, smoking or dyslipidemia, did not have any significant impact on the development of RD.

In our study, renal dysfunction was equally distributed between genders, despite the fact that cardiovascular diseases were more frequent in males compared to females. This could be explained by the physiological changes after menopause, most probably the loss of protective estrogen effect on vasculature. Estrogen decreases the expression of angiotensin type 1 receptor and angio- tensin-converting enzyme, and causes the release of angiotensinogen substrate (20).

In our study, systolic dysfunction ( $\leq 45 \%$ LVEF) was found to be a significant risk factor for $\mathrm{RD}$, with almost twice as high a risk, unlike diastolic dysfunction. However, in other studies, various relations between heart and kidney function parameters were found. Apparently, elevation in both ventricles' end-diastolic pressures and venous pressure contribute to RD by impairing forward blood flow and by increasing renal venous pressure (21). Predomination of a single process is probably influenced by the stage of heart disease and neurohormonal status of a patient. A decrease of LVEF was associated with acute RD in some chronic HF patients, and it was clear that low filling pressures can potentially worsen renal function (22). Acute renal injury, as a complication in congestive HF patients treated with diuretics, was observed more often in those with systolic (40\%) than diastolic dysfunction (28\%) (18). Worsening of renal function during the first 3 days of hospitalization was also reported in $47 \%$ of patients with acute decompensated HF (23). Additionally, $\mathrm{RD}$ is certainly favored by pronounced vasoconstriction and sodium retention in acute decompensated HF patients (22). The result of SD as the significant risk factor for kidney injury in our HF patients was likely due to its prolonged hypoperfusion effect on kidneys.

Urea, creatinine and eGFR were higher in our patients with RD older than 65 years compared to younger ones. As a consequence of HF related increase in venous pressure in kidneys, pressures in the interstitial space and Bowman's capsule also increase and lead to greater urea reabsorption. Besides, in low-output HF, arterial perfusion is maintained by the release of neurohumoral mediators, among which is arginine vasopressin that mediates urea reabsorption $(13,21)$. However, urea may not be a reliable index of RD, mostly compared to eGFR, because its serum concentrations are affected by different elements of metabolism $(13,24)$. This is perhaps the reason of insignificant correlation between LVEF and urea, nor creatinine values in our study.

We suppose that higher urea concentrations in our female patients were due to a lower percentage of total body water and significantly faster decline of eGFR with age, compared to males (25).

The limitation of our study was the lack of detailed therapeutic aspect overview, as many therapeutics for HF may compromise renal function.

\section{Conclusion}

Renal dysfunction is common in patients hospitalized with HF. We have demonstrated that systolic dysfunction, as well as patient age, were significant risk factors for the development of renal dysfunction. Our results indicate that age could be a better prognostic tool for identification of renal dysfunction in patients with heart damage. As for other evaluated parameters, diastolic dysfunction and gender did not have any significant im- 
pact on the development of renal dysfunction in cardiorenal syndromes 1 and 2 .

The results of our study may provide very important knowledge to the clinicians and make possible the prevention of irreversible changes in the elderly, who are under a greater risk for renal damage.

All authors declare no conflict of interest.

\section{References}

1. Ronco C. Cardiorenal and reno-cardiac syndromes: clinical disorders in search of a systematic definition. Int ] Artif Organs 2008;31: 1-2. [PubMed]

2. McCullough PA, Kellum JA, Mehta RL, Murray PT, Ronco C (eds). ADQI Consensus on AKI Biomarkers and Cardiorenal Syndromes. Contrib Nephrol. Basel, Karger, 2013;182: 82-98. [CrossRef]

3. McCullough PA, Aftab A. Cardiorenal syndromes. World J Cardiol 2011; 3: 1-9. [CrossRef][PubMed]

4. Carubelli V, Metra M, Lombardi C, et al. Renal dysfunction in acute heartfailure: epidemiology, mechanisms and assessment. Heart Fail Rev 2012;17:271-82. [CrossRef][PubMed]

5. Choudhary R, Gopal D, Kipper BA, Parra Landa A, Aramin $H$, Lee $E$, et al. Cardiorenal biomarkers in acute heart failure. Journal of Geriatric Cardiology. 2012;9:292-304. [CrossRef][PubMed]

6. Ronco C, McCullough $\mathrm{P}$, Anker SD, Anand I, Aspromonte N, Bagshaw SM, et al. Cardio-renal syndromes: report from the consensus conference of the Acute Dialysis Quality Initiative. Eur Heart J 2010;31:703-11. [CrossRef][PubMed]

7. Hawkins R. New biomarkers of acute kidney injury and the cardio-renal syndrome. Korean J Lab Med 2011;31:72-80. [CrossRef][PubMed]

8. Vishwanathan G, Gilbert S. The cardiorenal syndrome: Making the Connection. Int J Nephrol 2011;283137. [PubMed]

9. Acute and Chronic Heart Failure (Diagnosis and Treatment - ESC Clinical Practice Guidelines). Eur Heart J. 2008; 29: 2388-442. [CrossRef][PubMed]

10. Chavey WE 2nd, Blaum CS, Bleske BE, Harrison RV, Kesterson S, Nicklas JM. Guideline for the management of heart failure caused by systolic dysfunction: Part I. Guideline development, etiology and diagnosis.Am Fam Physician. 2001;64: 769-74. [PubMed]

11. Oh KJ, James B, Seward A, Taik J. The Echo Manual.3rd Lippincott Wiliams\& Wilkins inc. 2006.

12. Shiba N, Shimokawa H. Chronic kidney disease and heart failure--Bidirectional close link and common therapeutic goal. J Cardiol. 2011;57: 8-17. [CrossRef] [PubMed]

13. Giamouzis G, Kalogeropoulos AP, Butler J, Karayannis G, Georgiopoulou VV,Skoularigis J, et al. Epidemiology and importance of renal dysfunction in heart failure patients. Curr Heart Fail Rep. 2013;10: 411-20. [CrossRef][PubMed]
14. Carubelli V, Metra M, Lombardi C, et al. Renal dysfunction in acute heart failure: epidemiology, mechanisms and assessment. Heart Fail Rev 2012;17:271-82. [CrossRef][PubMed]

15. Smith GL, Lichtman JH, Bracken MB, et al. Renal impairment and outcomes in heart failure. J Am Coll Cardiol 2006;47:1987-96. [CrossRef] [PubMed]

16. Dries DL, Exner DV, Domanski MJ, Greenberg B, Stevenson LW. The prognostic implications of renal insufficiency in asymptomatic and symptomatic patients with left ventricular systolic dysfunction. J Am Coll Cardiol. 2000;35: 681-9. [CrossRef]

17. Anand IS, Bishu K, Rector TS, Ishani A, Kuskowski MA, Cohn JN. Proteinuria, chronic kidney disease, and the effect of an angiotensin receptor blocker in addition to an angiotensin-converting enzyme inhibitor in patients with moderate to severe heart failure. Circulation. 2009;120: 1577-84. [CrossRef] [PubMed]

18. Sun WY, Reiser IW, Chou SY. Risk factors for acute renal insufficiency induced by diuretics in patients with congestive heart failure. Am J Kidney Dis. 2006;47: 798-808. [CrossRef] [PubMed]

19. Nohria A, Hasselblad V, Stebbins A. Cardiorenal interactions: insights from the ESCAPE trial. J Am CollCardiol. 2008; 51: 1268-74. [CrossRef] [PubMed]

20. Suzuki H, Kondo K. Chronic kidney disease in postmenopausal women. Hypertens Res. 2012;35: 142-7. [CrossRef][PubMed]

21. Bock JS, Gottlieb SS. Cardiorenal Syndrome New Perspectives. Circulation. 2010;121: 2592-600. [CrossRef][PubMed]

22. Sarraf M, Masoumi A, Schrier RW. Cardiorenal syndrome in acute decompensated heart failure. CJASN. 2009;4: 2013-26. [CrossRef][PubMed]

23. Gottlieb SS, Abraham W, Butler J, Forman DE, Loh E, Massie BM, et al.The prognostic importance of different definitions of worsening renal function in congestive heart failure. Card Fail. 2002;8: 13641. [CrossRef]

24. Schrier RW. Blood Urea Nitrogen and Serum Creatinine - Not Married in Heart Failure. Circulation: Heart Failure. 2008;1: 2-5. [CrossRef] [PubMed]

25. Peters AM, Perry L, Hooker CA, Howard B, Neilly $M D$, Seshadri $N$, et al. Extracellular fluid volume and glomerular filtration rate in 1878 healthy potential renal transplant donors: effects of age, gender, obesity and scaling. Nephrol Dial Transplant. 2012;27: 1429-37. [CrossRef][PubMed] 


\title{
Originalni rad
}

UDC: 616.12-009.17:616.61

doi: $10.5633 / \mathrm{amm} .2017 .0419$

\section{UTICAJ STAROSTI I EJEKCIONE FRAKCIJE LEVE KOMORE NA POJAVU RENALNE DISFUNKCIJE KOD BOLESNIKA SA KARDIORENALNIM SINDROMOM TIP 1 I 2}

\author{
Dijana Stojanović ${ }^{1}$, Sonja Radenković1,2, Jelena Radović ${ }^{1}$, \\ Miodrag Stojanović ${ }^{3,5}$, Danijela Tasić ${ }^{3}$, Sandra Šarić4, \\ Valentina Mitić ${ }^{4}$
}

\footnotetext{
${ }^{1}$ Univerzitet u Nišu, Medicinski fakultet, Institut za patofiziologiju, Niš, Srbija

${ }^{2}$ Klinika za nefrologiju, dijalizu i transplantaciju, Klinički centar Niš, Srbija

${ }^{3}$ Institut za javno zdravlje Niš, Srbija

"Institut za lečenje i rehabilitaciju"Niška Banja", Niška Banja, Srbija

${ }^{5}$ Univerzitet u Nišu, Medicinski fakultet, Niš, Srbija
}

Kontakt: Dijana Stojanović

Bul. dr Zorana Đinđića 81, 18000 Niš, Srbija

E-mail: dijanam24@hotmail.com

Kardiorenalni sindrom tip 1 predstavlja akutnu dekompenzaciju srčane funkcije sa posledičnim smanjenjem ili gubitkom funkcije bubrega. Kardiorenalni sindrom tip 2 predstavlja postojanje hronične srčane slabosti, koja prouzrokuje nastanak hronične bubrežne bolesti. Cilj ispitivanja bilo je procena bubrežne funkcije kod hospitalizovanih bolesnika sa akutnom dekompenzacijom srčane slabosti i procena pojedinih faktora rizika za razvoj bubrežne disfunkcije.

Istraživanjem je obuhvaćeno 580 bolesnika sa srčanom slabošću, koji su u zavisnosti od postojanja bubrežne disfunkcije podeljeni u dve podgrupe. Bolesnici sa bubrežnom disfunkcijom (368 bolesnika, starosti 70,29 \pm 9,75 godina) su analizirani prema parametrima: godine, pol i tip srčane slabosti (sistolna ili dijastolna disfunkcija). Korišćena je logistička regresija za izračunavanje nezavisnih faktora rizika za jačinu glomerulske filtracije ispod $60 \mathrm{ml} / \mathrm{min} / 1,73 \mathrm{~m}^{2}$ sa $95 \%$ intervalom pouzdanosti. Među dobijenim faktorima rizika trebalo je proceniti najadekvatniji za smanjenje jačine glomerulske filtracije.

Bubrežna disfunkcija verifikovana je kod $63,44 \%$ bolesnika sa srčanom slabošću. Kao nezavisni faktori rizika za smanjenje jačine glomerulske filtracije izdvojili su se: godine bolesnika ( $O R=5,610 ; p<0,001)$ i postojanje sistolne disfunkcije $(O R=1,978$; $\mathrm{p}<0,001)$. Dijastolna disfunkcija i pol nisu imali uticaja na promenu funkcije bubrega.

Istraživanjem je dokazano da starost bolesnika i postojanje sistolne disfunkcije predstavljaju faktore rizika za smanjenje jačine glomerulske filtracije kod bolesnika sa akutnom dekompenzacijom srčane slabosti. Dijastolna disfunkcija i pol nisu pokazali isti značaj. Poređenjem njihovih OR, godine starosti imaju najveći značaj kao faktor rizika kod osoba sa kardiorenalnim sindromima tip 1 i tip 2.

Acta Medica Medianae 2017;56(4):120-125.

Ključne reči: godine starosti, kardiorenalni sindromi tip 1 i 2, sistolna disfunkcija, renalna disfunkcija 